\title{
Conceptual and Methodological Reflections on the Intersections of Religion, Ethics and Communication in the Context of the COVID-19 Pandemic
}

\author{
Mahlapahlapana Themane \\ University of Limpopo, South Africa \\ Email: Mahlapahlapana.themane@ul.ac.za \\ https://orcid.otg/0000-0002-2087-8538 \\ Email: mahlapahlapana.themane@ul.ac.za \\ Doi:
}

\begin{abstract}
Most of the work done to understand and combat the COVID-19 pandemic has been based on epidemiological models. These models are often devoid of human factors such as ethics, religion and communication. In this article, I endeavour to close this gap by examining whether or not religion can help in the understanding and management of the COVID-19 pandemic. Past research has made contradicting conclusions as to the influence of religion, ethics and communication on health. One body of research has concluded that strong religiosity results in greater adherence to health regulations because of the rule-abiding norms and philanthropic tendencies of religious people. On the contrary, another body of research concluded that stronger religiosity results in lower adherence as an intrusive personal and religious freedom. To address this quandary, this article attempts to answer two questions: One, what theoretical, procedural and epistemological questions does the COVID-19 pandemic invoke about the intersectionality of religion and health in the 21 first century? Two, how can we increasingly understand and discourse about the interactions of religion and health in the light of the COVID-19 pandemic without reifying and essentialising them? The article concludes by contending that an understanding of the objective and subjective nature of religion can provide the much needed nexus to understand and respond to the COVID-19 pandemic.
\end{abstract}

Keywords: religion, ethics, communication, COVID-19, culture, intersectionality.

\section{Introduction}

Generally, epidemiological models of the spread of the COVID-19 pandemic do not take into account human factors such as religion and ethics when seeking for answers to understand and manage it (Blazer \& Wu, 2011; De Franza, 2020). This is regrettable given the fact that when faced with adversity, many people resort to religion for answers (llievska \& Ilievski, 2020). Humans are religious beings by nature. Thus, religion is inextricably gnarled in a human being's spiritual and social life. People are also complex beings, and thus, the way religion interlaces itself through the matrix of human life is incredibly complex. Thus, any scientific or epidemiological intervention in the understanding and the curbing of disease outbreaks such as the COVID-19 pandemic, without considering such human value factors such as religion, ethics and communication, may be insufficient (Hart \& Koenig, 2020). Kowalczyk et al., (2020, p. 2676) asserts that: "... people experiencing fear, suffering or illness often experience a "spiritual renewal." Perhaps a new "generation of coronavirus" is being shaped, in which the development of spirituality will create the mature attitude based on truth and freedom". Therefore, health officials should try to explain their recommendations about dealing with disease outbreaks such as the COVID-19 pandemic through the eyes of religion, ethics and communication as well, if they are to succeed in their intervention efforts. 
Equally, specialists in the study of religion, communication and ethics should highlight their value and ethical decisions that impact behaviours relevant to the spread of the coronavirus. They need to explain, for example, where religion, ethics and communication could cause problems or where they may bring about possible solutions, and find creative alternative ways of thinking and writing about the COVID-19 pandemic. So a question such as: what does a virus have to do with religion, is ill-informed. Religion has much to offer and far more than the eye can see. Studies such as those by inter-alia DeFranza et al., (2020) and Antonenko, Willer and Keltner, (2013) that allude to the influence of religion on health abound. Antonenko, Willer and Keltner (2013) found that when strict regulations on disease control are forced, people tend to be less adherent to the regulations.

These studies, and many others, are advocating for the consideration of religion, ethics and communication in understanding and treatment of diseases such as depression. However, some have ignorantly described the use epidemiological models only as a panacea (Wildman et al., 2020). Chang et al. (2021) conducted a study in Taiwan comprising of four-hundred and fifty-eight healthcare workers recruited from general and psychiatric hospitals, and found that: "Religious faith can help individuals to cope with the stress of the pandemic, with Christianity/Catholicism elevating psychological well-being and Buddhism/Taoism decreasing mental distress and indirectly elevating the level of happiness of these healthcare workers". Thus, the influence of religion and ethics in matters related to the understanding and combating of the COVID-19 pandemic is not ignorable given that religion and ethics, including communication, are an integral part of people's lives (Walsh, 2009). Moreover, during times of pandemics, people turn to prayer for divine intervention, perhaps more but not only religion then depending on one's level of faith.

De Franza et al. (2020) argue that during times of crises such as pandemics, religious beliefs tend to be intensified. This has been so since time immemorial. Historically, calamities have increased religious beliefs and acceptance, this has been so from the ancient times to the recent past. For example, the 1918 Black Death pandemic caused unprecedented damage in some parts of Europe. Similarly, in the same year South Africa was hit hard by flue pandemic. In India, the smallpox pandemic caused huge misery. The September 11, 2001 attacks in the United States of America equally caused much harm. In a study of the USA September 11, 2001 disaster it was found that strong faith in God served as a buffer against trauma and other stress-related diseases (Osheim, 2008). All these pandemics elicited greater religiosity (Osheim, 2008; Poulin, Silver, Gil-Rivas, Torabi \& Seo, 2004; Holman \& Mclntosh, 2009; Ai, Cascio, Santangelo \& Evans-Campbell, 2005). Worldwide, calamities have been professed as a sign of divine anger leading to the creation of new divinities (Osheim, 2008). In the next section, I want to devote a few minutes to the relationship between health and religion in order to stress this point.

\section{Religion and health}

The history of religion and health dates back to 1897 with the work of Emile Durkheim, who argued, for example, that suicide rates within Europe, were advanced in Protestants areas as compared to the Catholic areas. He qualified this to be a results of a greater social cohesion and control by the Roman Catholic faith than within the Protestant faith (Van derWee, 1997). This was followed by the work of the Austrian psychologist Sigmund Freud (1856-1939), who argued that religion was an irrational and neurotic phenomenon (Van derWee, 1997). Since then numerous studies linking religion and health have increased dramatically. Most of these studies revealed the shielding effect of spiritual participation, especially church service attendance on health outcomes such as stress, depression, suicide, and personal well-being (Larson, 1993). 
Religion, ethics and communication appear to be the right lenses through which to assess the level of tolerance to those that have tested positive to the COVID-19 pandemic and their relatives, as well as the spreading of information where there is evidence in view of the coronavirus in South Africa, especially in rural areas where the English language is not accessible to the majority of the population. I align myself with Hart et al. (2020, p.1), who elegantly write:

\begin{abstract}
...that the present time is like no other in most of our lifetimes. We are all facing an uncertain future, with little control over what happens next. The only certainty for many now is their religious faith, which is a rock that they are now needing to hold onto. Indeed, religious faith will likely make an important difference in how many make it through this challenging time in our nation's and world's history.
\end{abstract}

In this article, I ask as to what are the consequences of the COVID-19 pandemic for religion, ethics and communication? Given the fact that the pandemic has existed just a few years now, there is still a scarcity of studies on the topic. Currently, there is little information, on the topic in the context of the COVID-19 pandemic (Henderson, 2021). Thus, the confirmation basis of this article largely derives from a limited empirical studies, and especially for those that show what is taking place in religious circles in the context of the COVID-19 pandemic. Thus, the current empirical and conceptual work contains insignificant reference to religion in responding to and in managing the COVID-19 pandemic (Dein, Loewenthal, Alan Lewis \& Kenneth, 2020). It is this literature gap that this article seeks to close.

While religion and spirituality have been defined differently from literature, various definitions of their meaning have emerged. Some of them have carried the psychological inclinations (Underwood \& Teresi, 2002), On the whole, empirical investigation on religion and health, used specific measures to define these concepts. The majority of them have used selfevaluation procedures of the two concepts, such as through the attendance of services attendance, private practices such as private devotions (Fetzer, 1999; Pargament et al., 2000; Hill \& Hood, 199; Underwood \& Teresi, 2002; Idler et al., 2003; Koenig \& Bussing, 2010).

Religion has always been associated with social functions in one way or the other (Maton \& Wells, 1995). This is often observable in relief efforts such as sponsoring welfare activities during crises. Many religious organisations and churches teach their followers to work to prevent and cure diseases through personal prayer and other devotions such as meditation or other forms of religious observation (Pollner, 1989). But, inadvertently, religion has also been associated with encouraging hedonistic behaviours such as extramarital sexuality, and violence on others (Cochran \& Beeghley, 1991). However, besides this cursory outlook, many studies have documented the benefits of religious involvement (Mochon, Norton \& Ariely, 2011).

More specifically, Balbuena, Baetz and Bowen's (2013) found that religion reduced depression incidence. Likewise, Miller, Warner, Wickramaratne and Weissman (1997) have shown that religion has an influence on depression. They found that individuals who affiliated as either Protestant or Catholic were less likely to experience episodes of major depression. These and other studies confirm the growing body of literature that religion is related to health (Smith, McCullough \& Poll, 2003)

Religious beliefs and practices are abundant within and across populations of the world. Approximately $84 \%$ of the world's devout populace is roughly distributed as follows: $31.5 \%$ Christianity, 23.2\% Islam, 15\% Hinduism, 7.1\% Buddhism, 5.9\%, 0.2\% Judaism, and 0.8\% Other (VanderWeele, 2015). South Africa, like other parts of the world, is a deeply religious country. It is a multi-religious country with almost $80 \%$ of the South African population adhering to the Christian faith. Other main religious groups are Hindus, Muslims and Jews. It is not clear 
from literature what percentage the African religions constitute. As a result, religious practices have always been an emotional aspect of society. Internationally and locally, it has been noted that in assistance activities such as HIV and AIDS, and Tuberculosis, governments have always been eager to work with faith communities rather than governmental undertakings or National Government Organisations in their efforts to respond to disasters (Kanji \& Agrawal, 2019).

Though the preceding discussion may appear to indicate that religion involves positivity with health, this is not always the case. While arguing for its positive predictions, for social impact such as pandemics there is the other side of the coin that needs attention. Inversely, this discussion so far points to its threat to impose pathological danger that may fuel pandemics such as COVID-19. Therefore, there is a need to avoid uninformed and simplistic tags of religion as being 'wholly good' or 'entirely bad'.

Against this backdrop, this article analyses responses of the religious community in South Africa, with special reference to the Christian faith in their response to the COVID-19 pandemic. It is hoped that the analysis will provide some commonalities and lessons on how to understand and to manage the COVID-19 pandemic through the eyes of religion. The following questions in the next section have been used to frame this analysis.

\section{Conceptual framework, methodological and epistemological questions}

Science stresses the fact that definition of terms should always be unambiguous, if we are to reach precision. This should be done not by reducing their obscurity of nebulousness, but rather by keeping well within it, and, by carefully phrasing our sentences in such a way that the possible shadows of meaning do not matter (Oman, 2013). Thus, this ensuing section seeks to explain what the concepts religion, ethics and communication entail in order to use them more appropriately in this article.

Although religion, ethics and communication have been subject of much study in the past, scholars have struggled to find a single definition that can combine their multidimensional nature. The scope of this article dares to enter such a debate. However, it is important to provide some working concept that this article has adopted. The term religion "comes from the Latin root religio, which indicates a bond between humanity and a god (Hill et al., 2000:56). Scholars identify at least three historical designations of the term: 1) a supernatural power to which individuals are inspired or committed; 2) a sensation present in the individual who conceives such powerful; and 3) the ceremonial performances carried out in respect of that deity (Wulff, 1997).

This classification is useful in that it provides a broad framework that houses both the objective and the subjective meanings of the word; which allows users some fluctuation between its abstract and the existing objective reality expressed through a definite definable system (such as denominations, theological customs, main world religions). Wulff (1997) maintains that religion has become progressively reified in modern society; that is religion is regularly transformed from an intangible process to a fixed unbiased entity. However, Smith III (1962) cautions against simple classifications as they may lead to the reification of religion because it may lead to a serious distortion and devaluation since it overlooks the forceful personal quality of much religious experience.

\section{Ethics and health}

Equally, the concept ethics remains central in the understanding and treatment of the COVID19 pandemic. Despite, the scientific, technological advances, pluralistic worldviews and advanced communication, ethics remain important in how people react to issues of life such 
as the COVID-19 pandemic. The concept of ethics is usually defined as the ethical values that rule a person's behaviour or their conduct in their everyday life activities such as work. The term ethics is very controversial in the sense that people differ in terms of what constitutes what is wrong or right. It becomes a dilemma to ascertain this for many people in the modern world in which we live. Consequently, there is seemingly very little agreement regarding desired standards of good or ethical behaviour. One's world-view and culture invariably influence and shape human opinions on ethics and what constitutes 'good' behaviour (Nicolaides, 2020). Moral life with its wide range of exclusions and virtues is of necessity grounded in a God who is a transcendent being. Failing such a grounding, humanity is vulnerable to secular relativism that by its very nature, weakens the moral fabric of society (Nicolaides, 2020). Ethics are, according some, normally based on personal opinion, and this makes it difficult to arrive at a definite meaning of what it is. However, health workers, teachers and other sectors of society should have a basic understanding of the term if they factor it in their interventions. Any intervention that ignores the intersectionality of ethics, religion and health is unlikely to succeed (Malone, 2020).

Historically, the term ethics is a branch of philosophy that is used to study human behaviour and ideal ways of acting. The term can be traced back to Emmanuel Kant (1724-1804). Kant's ethics defined ethics as the way one should always behave towards other people. He further argued that one should only act in accordance with rules that could hold for everyone that is what you would like to be the universal rule (Kant, 2003). This definition could be useful in understanding how ethics can help in the managing of the COVID-19 pandemic. For example, in rollout of the vaccination programme. Some sections of the South African society are said to be resisting to be vaccinated because think it a wrong to do. Their bone of argument is that vaccination has some side effects. Respecting the views of the other person is key to understanding their moral behaviour. Without due respect of others (norms and values), health workers may not win the battle against the COVID-19 pandemic. Therefore, since ethics are an active process rather than static one, it is imperative that researchers should continually interrogate attitudes, values, behaviours and performances of people in the intersectionality of the three (ethics, communication and religion) in the context of the COVID-19 pandemic.

\section{Communication and health}

Besides the intersectionality, a religion and ethics conceptual framework in the understating and management of COVID-19 communication could be regarded is one important social determinants of health (SDH). This is even more important given the advent of social media in recent years. I concur with Ataguba and Ataguba (2020) that different communication strategies during the COVID-19 pandemic can lead to misrepresentation and consequently mistrust in efforts to combat the pandemic, especially in low income countries like South Africa. For example, information about issues related to the COVID-19 pandemic are predominantly communicated in English, which the majority of the elderly generation cannot follow. This is common in the majority of low-income countries in the region and countries in terms of traditional, dialectal and cultural diversity. This should be an important consideration in ensuring effective communication about issues such as the COVID-19 pandemic (Ataguba, 2020).

\section{Through the eyes of the Resurrection}

The need to consider religious matters can be best illustrated by the concept of the Resurrection as embodied in the person of Christ. The Gospel of Christ, especially its doctrine of the Resurrection, harmonises in itself the subjective and objective elements of religion. On the one hand, it rests on a fact which is however exclusive, yet claims to belong to the circles of human knowledge. On the other hand, the fact is that its individual appropriation offers a scope for a spiritual life. The Gospel of Christ claims to take religion out of the domain of the notion, and rests its hopes upon the forces exterior to the believer. 
This article uses the former to provide a framework through which we can understand the meaning and impact on the COVID-19 pandemic. Such a conceptualisation is so far-reaching in its ultimate significance as to present itself to every age and every soul with fresh power. It gives faith a firm standing in history, and at the same time opens a boundless vision of the future development of our present powers. Its purports to bring down to earth our understanding of religion in the Emmanuel (God is with us) (Matthew 1:22-23), and at the same time justifies the infinitude of temporal existence.

By its definiteness and real incidences, the doctrine of the Resurrection gives self-esteem to all human action by the universality of its import (Perkins, 2007). It lifts the thoughts of the believer to man, then to the race, and to the world. In other words, it stands between the perceived and the non-perceived. It belongs, similarly, to the divine and the physical order, and reconciles both of them. In both respects, the teaching of the Resurrection is indispensable to the Christian faith. This article is therefore embedded in the third classification by Wulff (1997), namely that the ritual acts carried out by Christ's followers are in respect of that power, e.g. to go into the whole world, preach the Gospel and heal the sick (Matthew 28:17-18).

Alternatively, it gives an immediate reality to the one by the appearance of the Son of man, who came from his Father and went back to his Father. It empowers the other by the exposure of a divine presence in the world according to His word, who said: "Lo I am with you to the close of the age" (Matthew 28:20). This article is therefore embedded in the third classification by Wulff (1997), namely that the ritual acts carried out by Christ's followers are in respect of that power, e.g. to go into the whole world, preach the Gospel and heal the sick (Matthew 28:17-18).

\section{Through the eyes of the Socio-Cultural Theory}

Rounding out the framework of this article is the Socio-Cultural Theory, which provides a framework for understanding the relationship between culture and religion. It addresses religious ecologies such as attitudes, values, and practices concerning nature within the world's religions and outside of those traditions. It identifies ways of interacting with nature or divinity that inspire human responses of respect, and protection (Chang, 2013).

The tenets of the Socio-Cultural theory seem appropriate to provide lenses through which to examine the intersectionality of culture, ethics, communication and religion in addressing the impact of the COVID-19 pandemic. To preface this conceptual framework, firstly, I need to point out that many intellectuals and academics have attempted in vain to provide a definition of religion that includes all religions (Silver, 2019). This is partly due to what I have referred to earlier: the fact that it is a multi-dimensional social construct. It can be explained as the study of thoughts, experiences, beliefs, values, and behaviours that are related with God (Hill, Pargament, Hood, McCullough, Swyers, Larson \& Zinnbauer, 2000).

Within it one can differentiate between the psyche from the pneuma (Van de Kemp, 1996). The struggle to find a definitive conceptualisation makes it difficult to draw a line between the two. This complexity makes the study of its nature and influence on various aspects of life challenging and problematic (DeFranza et al., 2020). A significant body of literature (Mathras, Cohen, Mandel \& Mick, 2016; Scala \& Johnson, 2017; McClure, 2017) has pointed out the multidimensional nature of religion and ethics. For the purposes of this article, I focussed on the cultural dimension of religion and ethics to address issues raised by the COVID-19 pandemic. In particular, how it indexes beliefs and behaviours to provide a layered understanding of the pandemic and how it can be responded to.

It is against this background that I framed this article under the following socio-cultural concepts to leverage my understanding of how religiosity as a socio-cultural construct can be 
used to respond to the pandemic. The concepts include social support and divine support, obligation to follow rules, self-control and longevity.

\section{Social and divine support}

To examine whether religion would hamper or ease adherence to the COVID-19 pandemic or not, I was guided by two kinds of research that hold contrasting views. One, that religiosity provides a social capital such as 'onethering' each other or taking care of each other. For example, the Bible exhorts believers to care for one another over 830 times. This may provide a social support platform for encouraging one another to adhere to COVID-19 restrictions (Fox \& Tabory, 2008; lyer, 2016). This stream of research reflects the enabling power of religion to support adherence through solidarity such as house visitations, prayer meetings, etc. On the other hand, another stream of research points out that when religiosity increases, people gain support of a greater support from the divine power. Therefore, they may feel that it is not necessary to adhere to the COVID-19 pandemic restrictions that are imposed by government, such as social distancing and wearing of masks. Thus, faith is a critical aspect in life for many. Wu and Cutright (2018) aver that increased reliance on the divine intervention may reduce compliance with fear-based recommendations.

\section{Obligation to follow rules}

Another useful concept to understand how religiosity can impact on adherence or nonadherence to the COVID-19 pandemic is the tendency by the religious community to obey rules. Torgler (2006) found that religion inculcates an obligation to follow rules. For example, it may increase tax compliance. This behaviour may predict that where religiosity increases, it is likely that the COVID-19 regulations may be adhered to in the fear of God as the Apostle Paul admonishes:

The authorities that exist have been established by God. Consequently, he who rebels against the authority is rebelling against what God has instituted, and those who do so will bring judgment on themselves. For rulers hold no terror for those who do right, but for those who do wrong... (Romans 13:1-4) (New International Version, 1996).

This same idea is encapsulated by the Islam region in Quran 4: 59, with this injunction:

Oh ye who believe! Obey Allah and obey the messenger, and those in authority among you. If you differ in anything among yourself, refer it to Allah and his messenger, if ye do believe in Allah and the last day; that is best, and most suitable for final determination.

Such obligations as cited above are even more pronounced if such believers were inculcated with the rules of religion from a young age. The question then is: can an increased religiosity foster adherence to the COVID-19?

\section{Self-control}

Something of the same notion, as the tendency of religious people to follow rules acquiescently, is its influence to instil self-control. DeFranza et al. (2020, p.2) rightly state: "Moreover, religiosity promotes greater self-control, which in turn helps people follow rules more easily because they can control their desire to break rules". The same idea is echoed by Desmond, Ulmer and Bader (2013), who found that religious youth exhibit higher levels of selfcontrol when it came to alcohol and marijuana abuse. These studies and many others underlie the need for an eclectic approach that takes into account the intersectionality of religion in the promotion of health, such as the management of the COVID-19 pandemic. Taken together, 
this kind of research suggests that greater readiness to abide by the rules and intensified selfcontrol, which are associated with religiosity, can result in greater adherence to the COVID19 pandemic regulations. But, as I have stated earlier, such a conclusion should be arrived at cautiously.

Thus, these two theoretical perspectives can be important in framing our understanding of COVID-19 and how it can be responded to. Central to them is the fact that although epidemiological models are good, they are not good enough There is a need for an eclectic model that takes into account religious and cultural factors (Kowalczyk, Roszkowski, Montane, Pawliszak, Tylkowski, \& Bajek, 2020). In the next section, I continue with the same subject by providing practical examples to embolden my thesis, starting with the first question: What methodological, conceptual, and epistemological questions does the pandemic invoke about the intersectionality of religion and health in the 21 first century?

In addressing this question, let me start by describing some Christian responses to the COVID19 pandemic. Such views or beliefs may also appear in other spiritual groups which believe that apocalyptic change is imminent (Dein, Loewenthal, Lewis \& Pargament, 2020). Biblical apocalypse is describing issues related to the end times or destruction of the world. Here is a perfect example of the intersectionality of religion and health. Since the COVID-19 pandemic has raised worldwide concerns and doubts, several social groups, including the religious community, have entrenched conspiracy theories within the apocalyptic thought to clarify and seek to find meaning in the pandemic (Sturm \& Albrecht, 2021). These concerns and anxieties raise deep methodological and epistemology questions that go beyond epidemiological questions.

Social theory appears appropriate to engage the questions of the intersectionality between religion, ethics and communication. Countries in their management of diseases seem to overlook the importance of considering the human factors. This gap can be illustrated with this example from the Sunday Times newspaper. I was attracted to an article written by Philani Nombembe, entitled: 'Inyangas, feeling snubbed, snub jab' (Nomembe, 2021, p. 11) in which he highlights that traditional healers are discouraging their clients who they claim are the majority of the population, from having a COVID-19 vaccination. He says that traditional healers are upset that the government has failed to educate the population about the sideeffects and efficacy of the vaccinations. On the whole, he concludes that traditional healers and their followers feel that divine powers can intervene to deal with the COVID-19 pandemic. This is a perfect example of the intersection between religion, ethics and science. If the war against the pandemic is to be won, it is here that a nexus should be sought. Another example of the intersectionality of this tripartite alliance between religion, ethics and the COVID-19 pandemic is how the virus spread through the ambit of religion in South Korea. Wildman, Bulbulia, Sosis and Schjoedt (2020) report that a number of people were infected because of their inflexible adherence to their religious beliefs. The same can be said about some people in Trinidad who continued to hold in-person services.

Although recalcitrant religious congregations may be guilty of viral transmissions, it is noteworthy that a number of religious groups try hard to control the spread of the pandemic. For instance, most religious communities across the world have resorted to online services. Also, many are involved in distributing basic health information and are presenting crucial financial assistance to those living in debasing economic conditions. This notwithstanding, the behaviours of religious groups are attracting the attention of some deviant groups, but in many ways religious communities are more advantageous than detrimental in society. While it is difficult to give an accurate figure of the global diversity of religious communities worldwide, the fact that so many faith-based groups are active in the fight against pandemics such as the COVID-19 pandemic, it is a vivid reminder that religion does not always profile human behaviours neatly at any single point. For this reason, the question of whether religion is 
contributing to the global COVID-19 health crisis is poorly expressed and needs to be reformulated (Wildman, Bulbulia, Sosis \& Schjoedt, 2020).

It is hoped that efforts such as those taken by this article should be able to allow people to make informative, insightful generalisations where possible, but that needs to done carefully. Though I think that the question of whether or not religion is a force for help or harm is illformed, we nevertheless might ask whether there are recurring features across religious retorts to the COVID-19 pandemic. Religious groups, it appears, do not line up neatly with the global pandemic response, however, some religious community-making tends to be an intensifier of change, strengthening the resolve and motivating actions despite the restless and promethean nature of religion.

A comparable story could be expressed about the role of religion during the civil rights movement in the United States of America or in South Africa. In South Africa, resistance against apartheid was spearheaded by the South African Council of Churches. Today, the same kind of associations of faith-based communities and secular groups can be found in many parts of the world. Knowing that people belong to a faith-based grouping can readily tell us about their ethical judgments and how they will communicate what they believe in openly and frankly. Also, knowing about the religiosity can often predict the level of motivation and interest to approach contentious issues faced in life such as whether to take a vaccine against the coronavirus or not. Religion makes many battles ethical issues and thus stronger and more self-assured. Returning to the COVID-19 matter, we can conclusively say that religion may impact the viral spread either by inhibiting or accelerating social transmission, depending on the specific religious group being considered or studied and what they advocate to their adherents.

\section{Conclusion}

This article has argued for the consideration of human factors such as religion, ethics and communication in an effort to understand and manage the COVID-19 pandemic. It seeks to encourage researchers to reflect on the intersectional aspects of human factors discussed here, and thereby to stop erroneous thinking about religion as a mere nonentity in the fight against pandemics such as the COVID-19. While there has been a growing number of articles exploring the effects of religion and the COVID-19 pandemic in the past two years, the issues I have raised here, especially the intersectionality of religion, ethics and communication, are not only new, but also mostly ignored. The use of the two conceptual frameworks: Doctrine of the Resurrection and the Socio-Cultural Theory and propositions, have sought to reveal the role that religion can play in conjunction with ethics and communication. Thinking of religion, communication and ethics in this way is even richer and more promising than epidemiologists could normally consider.

\section{References}

Ataguba, O. A. \& Ataguba, J. E. (2020). Social determinants of health: the role of effective communication in the COVID-19 pandemic in developing countries. Global health action, 13(1), 1-6.

Ataguba, J.E. (2020). COVID-19 Pandemic, a War to be Won: Understanding its Economic Implications for Africa. Applied Health Econ Health Policy (18), 325-328 [Available online at https://doi.org/10.1007/s40258-020-00580-x]

Antonenko Young, O., Willer, R. \& Keltner, D. (2013). "Thou shalt not kill": Religious fundamentalism, conservatism, and rule-based moral processing. Psychology of Religion and Spirituality, 5(2), 110. 
Balbuena, L., Baetz, M. \& Bowen, R. (2013). Religious attendance, spirituality, and major depression in Canada: A 14-year follow-up study. The Canadian Journal of Psychiatry, 58(4), 225-232.

Blazer, D. G. \& Wu, L. T. (2011). The epidemiology of alcohol use disorders and subthreshold dependence in a middle-aged and elderly community sample. The American Journal of Geriatric Psychiatry, 19(8), 685-694.

Chang, M-C, Chen, P-F, Lee, T-H, Lin, C-C, Chiang, K-T, Tsai, M-F, Kuo, H-F. \& Lung, F-W. (2021). The Effect of Religion on Psychological Resilience in Healthcare Workers During the Coronavirus Disease 2019 Pandemic, Frontiers in Psychology, 12.

Chang, B. (2013). Voice of the voiceless? Multi-ethnic student voices in critical approaches to race, pedagogy, literacy and agency. Linguistics and Education, 24(3), 348-360.

Cochran, J. K. \& Beeghley, L. (1991). The influence of religion on attitudes toward non-marital sexuality: A preliminary assessment of reference group theory. Journal for the Scientific Study of Religion, 30 (1), 45-62.

DeFranza, D., Lindow, M., Harrison, K., Mishra, A. \& Mishra, H. (2020). Religion and reactance to COVID-19 mitigation guidelines. American Psychologist. [Available online at https://doi.org/10.1037/amp0000717]

Dein, S., Loewenthal, K., Lewis, C.A. \& Pargament, K.I. (2020). COVID-19, mental health and religion: An agenda for future research. Mental Health, Religion \& Culture, 23 (1), pp. 1-9. DOI: 10.1080/13674676.2020.1768725.

Desmond, S. A., Ulmer, J. T. \& Bader, C. D. (2013). Religion, self-control, and substance use. Deviant Behavior, 34(5), 384-406.

Hart, C. W. \& Koenig, H. G. (2020). Religion and health during the COVID-19 pandemic. Journal of Religion and Health, 1(15), 1-3. doi: 10.1007/s10943-020-01042-3

Hill, P. C. \& Hood, R. W. (Eds.). (1999). Measures of religiosity (pp. 119-58). Birmingham, AL: Religious Education Press.

Henderson, E. S. (2021). A Global Perspective on the COVID-19 Crisis and an Ontological Theology Perspective. Pharos Journal of Theology ISSN2414-3324 online Volume 102 Article 12 (2021), 102(2021).

Fox, J. \& Tabory, E. (2008). Contemporary evidence regarding the impact of state regulation of religion on religious participation and belief. Sociology of Religion, 30 (1), 245-271.

Hill, P.C., Pargament, K.I., Hood, R.W., McCullough, J.M.E., Swyers, J.P., Larson, D.B. \& Zinnbauer, B.J., 2000. Conceptualizing religion and spirituality: Points of commonality, points of departure. Journal for the theory of social behaviour, 30(1), pp.51-77.

Green, J., Edgerton, J., Naftel, D., Shoub, K. \& Cranmer, S. J. (2020). Elusive consensus: Polarization in elite communication on the COVID-19 pandemic. Science Advances, 6(28), eabc2717.

lyer, S. (2016). The new economics of religion. Journal of Economic Literature, 54(2), 395441. 
Larson, J. S. (1993). The measurement of social well-being. Social indicators research, 28(3), 285-296.

Ilievska, A. \& llievski, N. (2020). Spiritual Resilience and Transactional Analysis ModelHolistic Paradigm for Facing a Global Crisis. European Journal of Interdisciplinary Studies, 6(2), 126-130.

Kanji, R. \& Agrawal, R. (2019). Building a society conducive to the use of corporate social responsibility as a tool to develop disaster resilience with sustainable development as the goal: an interpretive structural modelling approach in the Indian context. Asian Journal of Sustainability and Social Responsibility, 4(1), 1-25.

Kant, I. (2003). Theoretical Philosophy, 1755-1770. London: Cambridge University Press.

Kowalczyk, O., Roszkowski, K., Montane, X., Pawliszak, W., Tylkowski, B. \& Bajek, A. (2020). Religion and faith perception in a pandemic of COVID-19. Journal of Religion and Health, 59(6), 2671-2677.

Mathras, D., Cohen, A. B., Mandel, N. \& Mick, D. G. (2016). The effects of religion on consumer behavior: A conceptual framework and research agenda. Journal of Consumer Psychology, 26(2), 298-311.

Malone, D. M. (2020). Ethics education in teacher preparation: a case for stakeholder responsibility. Ethics and Education, 15(1), 77-97.

McClure, P. K. (2017). Tinkering with technology and religion in the digital age: The effects of Internet use on religious belief, behaviour, and belonging. Journal for the Scientific Study of Religion, 56(3), 481-497.

Miller, L., Warner, V., Wickramaratne, P. \& Weissman, M. (1997). Religiosity and depression: Ten-year follow-up of depressed mothers and offspring. Journal of the American Academy of Child \& Adolescent Psychiatry, 36(10), 1416-1425.

Nicolaides, A. (2020). Contemplating Christian ethics and spirituality for sound leadership in organisations, Pharos Journal of Theology, 101.

Oman, D. \& Paranjpe, A. C. (2018). Indian Spirituality: How Relevant is Pargament's Framework? Psychological Studies, 63(2), 140-152.

Osheim, D. J. (2008). Religion and epidemic disease. Historically Speaking, 9(7), 36-37.

Perkins, P. (2007). The Resurrection of Jesus: John Dominic Crossan and NT Wright in Dialogue. Edited by Robert B. Stewart. Minneapolis, MN: Fortress, 2006. xix +220 pages. \$18.00. Horizons, 34(2), 360-361.

Pollner, M. (1989). Divine relations, social relations, and well-being. Journal of health and social behavior, 92(104).

Poulin, M. J., Silver, R. C., Gil-Rivas, V., Holman, E. A. \& Mclntosh, D. N. (2009). Finding social benefits after a collective trauma: perceiving societal changes and well-being following 9/11. Journal of Traumatic Stress: Official Publication of the International Society for Traumatic Stress Studies, 22(2), 81-90.

Quran 2:4-5, Oxford World's Classics edition 
Silver, C. F. (2019). The psychology of religion: An empirical approach, written by Hood, R.W. Jr., Hill, PC \& Spilka, B. Journal of Empirical Theology, 32(1), 163-164.

Torgler, B. (2006). The importance of faith: Tax morale and religiosity. Journal of economic Behaviour \& organization, 61(1), 81-109.

Smith, T. B., McCullough, M. E. \& Poll, J. (2003). Religiousness and depression: evidence for a main effect and the moderating influence of stressful life events. Psychological bulletin, 129(4), 614.

Smith III, J. W. (1962). Religion A / Religion B: A Kierkegaard Study. Scottish Journal of Theology, 15(3), 245-265.

Sturm, T. \& Albrecht, T. (2021). Constituent Covid-19 apocalypses: contagious conspiracism, 5G, and viral vaccinations. Anthropology \& Medicine, 28(1), 122-139.

Torabi, M. R. \& Seo, D. C. (2004). National study of behavioral and life changes since September 11. Health Education \& Behavior, 31(2), 179-192.

Vande Kemp, H. (1996). Historical perspective: Religion and clinical psychology in America. In E. P. Shafranske (Ed.), Religion and the clinical practice of psychology (pp. 71-112). American Psychological Association. https://doi.org/10.1037/10199-003.

VanderWeele, T. (2015). Explanation in causal inference: methods for mediation and interaction. London: Oxford University Press.

Wildman, W.J., Bulbulia, J., Sosis, R. \& Schjoedt, U. (2020). Religion and the COVID-19 pandemic. Religion, Brain \& Behaviour, 10(2),115-117, DOI:

10.1080/2153599X.2020.1749339.

Walsh, F. (2009). Religion, spirituality, and the family: Multi-faith perspectives. In F. Walsh (Ed.), Spiritual resources in family therapy (pp. 3-30). Guilford Press.

Wood, C. (2017). Ritual well-being: Toward a social signalling model of religion and mental health. Religion, Brain \& Behaviour, 7(3), 223-243.

Wulff, D.M. (1997). Psychology of religion. Classic \&Contemporary (2nd ed.). Hamilton: Hamilton Printing.

Wu, E.C. \& Cutright, K.M. (2018). In God's hands: How reminders of God dampen the effectiveness of fear appeals. Journal of Marketing Research, 55(1),119-131. 